\title{
Double hit lymphoma presenting as haemophagocytic lymphohistiocytosis
}

\author{
Xavier Issac Rivera, ${ }^{1}$ Lee J McGhan, ${ }^{2}$ Jonathan H Schatz, ${ }^{3}$ Soham D Puvvada ${ }^{1}$
}

'Division of Hematology and Oncology, Department of Medicine, University of Arizona Cancer Center, Tucson, Arizona, USA

${ }^{2}$ Department of Pathology, University of Arizona Cancer Center, Tucson, USA ${ }^{3}$ Department of Medicine, Division of Hematology, University of Miami Miller School of Medicine Palm Beach Regional Campus, Miami, Florida, USA

\section{Correspondence to} Mr Xavier Issac Rivera xirivera@email.arizona.edu

XIR and LJMG contributed equally.

Accepted 1 May 2017

\section{CrossMark}

\section{To cite: Rivera XI,} McGhan LJ, Schatz JH, et al. BMJ Case Rep Published Online First: [please include Day Month Year]. doi:10.1136/bcr-2017220401

\section{DESCRIPTION}

A 67-year-old woman with history of severe rheumatoid arthritis and use of multiple biologics including infliximab, tocilizumab and abatacept presented with fever of $39.1^{\circ} \mathrm{C}$ and severe pancytopenia (white blood cell count $(\mathrm{WBC})=1.0 \times 10^{9} / \mathrm{L}, \quad$ absolute neutrophil count $(\mathrm{ANC})=0.55 \times 10^{9} / \mathrm{L}$, haemoglobin $=8.7 \mathrm{~g} /$ $\mathrm{dL}$, platelets $\left.=46 \times 10^{9} / \mathrm{L}\right)$. As part of the pancytopenia evaluation, imaging (CT of the chest, abdomen and pelvis) showed diffuse lymphadenopathy. Further evaluation revealed an elevated ferritin $(8564 \mathrm{ng} / \mathrm{mL})$, hypofibrinogenaemia (fibrinogen $=95 \mathrm{mg} / \mathrm{dL}$ ), elevated triglycerides $(399 \mathrm{mg} / \mathrm{dL})$ and a soluble interleukin 2 receptor level of 41167 units/mL, satisfying diagnostic criteria for haemophagocytic lymphohistiocytosis (HLH). A subsequent bone marrow biopsy also revealed morphological evidence of haemophagocytosis (figure 1A), in addition to a population of very large and atypical mononuclear cells with markedly irregular, folded nuclear contours, prominent nucleoli and moderate amounts of cytoplasm (figure 1B,C). A similar large cell infiltrate was identified in the left axillary lymph node, causing complete effacement of nodal architecture (figure 1D). Immunohistochemistry performed on tissue sections revealed the neoplastic cells to be positive for PAX5 and CD20, both B-cell markers, in addition to CD45, BCL6, MUM1 and weak CD30. BCL2 and T-cell marker CD2 were also aberrantly expressed. The neoplastic cells were negative for CD10, CD15, MYC and cyclin D1. $\mathrm{Ki}-67$, a proliferation marker, was positive in more than $90 \%$ of the neoplastic cells. Fluorescence

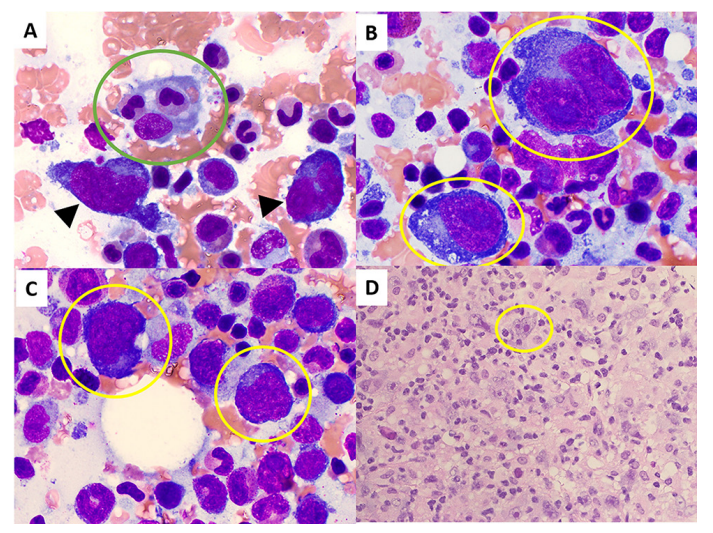

Figure 1 (A) $100 \times$ Wright-Giemsa haemophagocytosis by a macrophage (circled); $(B, C) 100 \times$ Wright-Giemsa large neoplastic cells (circled) and (D) 40× H\&E left axillary lymph node. in situ hybridisation showed rearrangements of MYC and BCL6, confirming a diagnosis of double hit lymphoma (DHL). She was treated with dose adjusted-etoposide + prednisone + vincristine (Oncovin) + cyclophoshamide + doxorubicin (Hydroxydaunorubicin) - rituximab (DA-EPOCH-R). Furthermore, she had low-level central nervous system involvement in her cerebrospinal fluid (CSF) by flow cytometry which was treated with intrathecal therapy resulting in clearing of her CSF. Her 'HLH indices' clinically resolved after one cycle of chemotherapy, with normalisation of her counts. She is now doing well clinically, and recent positron emission tomography scan shows complete response to therapy with resolution of all abdominal and thoracic adenopathy.

Defects in cytotoxic $\mathrm{T}$ cells and natural killer cells are seen in all cases of HLH. ${ }^{1}$ HLH is typically associated with T-cell malignancies, with only rare reported associations with B-cell lymphomas. ${ }^{1}$

The current WHO definition of DHL requires the occurrence of a $M Y C$ rearrangement along with $B C L 2$ or BCL 6 rearrangements. ${ }^{2}$ Patients typically have advanced stage disease, with elevated lactate dehydrogenase, high international prognostic index scores and poor outcomes. ${ }^{2}$ Multiple retrospective series show that rituximab (Mabthera) - cyclophosphamide + doxorubicin (Hydroxydaunomycin) + vincristine (Oncovin) + prednisolone (R-CHOP) is an insufficient therapy in patients with DHL with median overall survival of 10 months or less. ${ }^{2}$ Although there were no detectable differences between the augmented regimens, the use of R-CHOP had inferior survival compared with all other treatments with a HR of 0.53 . DA-EPOCH-R has been associated with high overall response rates and longer event-free

\section{Learning points}

Fever, cytopenias and elevated ferritin should raise strong clinical suspicion for haemophagocytic lymphohistiocytosis (HLH), a rare but potentially fatal disorder that requires prompt recognition and treatment.

- Therapy of secondary HLH is based on the treatment of its underlying aetiology: the high-grade lymphoma in this case.

- Double hit lymphomas are aggressive lymphomas with frequent central nervous system involvement, poor overall prognosis and represent an unmet medical need. 
survival. ${ }^{2}$ Along with the choice of the optimal chemoimmunotherapy backbone, the role of high-dose therapy in DHL is undefined and should be considered on a case-by-case basis. ${ }^{2}$

In summary, this is the first documented case of DHL presenting as HLH (to our knowledge). While ongoing advances in targeted MYC and BCL2 inhibition with agents such as venetoclax show promising results, ${ }^{3}$ this represents an unmet medical need in lymphoma.

Contributors XIR wrote the paper, prepared clinical images for publication, prepared manuscript for publication and approved the manuscript. LJM obtained and interpreted clinical images for publication, prepared clinical images for publication and approved the manuscript. JHS treated the patient, analysed the data providing clinical interpretations and approved the manuscript. SDP treated the patient, analysed the data providing clinical interpretations, wrote the paper and approved the manuscript.
Competing interests None declared.

Patient consent Consent obtained from guardian.

Provenance and peer review Not commissioned; externally peer reviewed.

(C) BMJ Publishing Group Ltd (unless otherwise stated in the text of the article) 2017. All rights reserved. No commercial use is permitted unless otherwise expressly granted.

\section{REFERENCES}

1 Usmani GN, Woda BA, Newburger PE. Advances in understanding the pathogenesis of HLH. Br J Haematol 2013;161:609-22.

2 Petrich AM, Gandhi M, Jovanovic B, et al. Impact of induction regimen and stem cell transplantation on outcomes in double-hit lymphoma: a multicenter retrospective analysis. Blood 2014;124:2354-61.

3 Delmore JE, Issa GC, Lemieux ME, et al. BET bromodomain inhibition as a therapeutic strategy to target c-Myc. Cel/ 2011;146:904-17.

Copyright 2017 BMJ Publishing Group. All rights reserved. For permission to reuse any of this content visit http://group.bmj.com/group/rights-licensing/permissions.

BMJ Case Report Fellows may re-use this article for personal use and teaching without any further permission.

Become a Fellow of BMJ Case Reports today and you can:

- Submit as many cases as you like

- Enjoy fast sympathetic peer review and rapid publication of accepted articles

- Access all the published articles

- Re-use any of the published material for personal use and teaching without further permission

For information on Institutional Fellowships contact consortiasales@bmjgroup.com

Visit casereports.bmj.com for more articles like this and to become a Fellow 